\title{
COMPELLING GOD
}

Theories of Prayer in Anglo-Saxon England 



\section{Compelling God}

Theories of Prayer in Anglo-Saxon England

STEPHANIE CLARK 
(C) University of Toronto Press 2018

Toronto Buffalo London

utorontopress.com

Printed in the U.S.A.

ISBN 978-1-4875-0198-3

$\infty$

Printed on acid-free, $100 \%$ post-consumer recycled paper with vegetable-based inks.

\section{Library and Archives Canada Cataloguing in Publication}

Clark, Stephanie, 1975-, author

Compelling God : prayer in Anglo-Saxon England / Stephanie Clark.

(Toronto Anglo-Saxon series ; 26)

Includes bibliographical references and index.

ISBN 978-1-4875-0198-3 (cloth)

1. English literature - Old English, ca. 450-1100 - History and criticism.

2. Christian literature, Latin (Medieval and modern) - England - History and criticism. 3. Prayer - Christianity - History - To 1500. 4. Prayers, Early Christian - England. 5. Prayer in literature. 6. Spirituality in literature.

7. Bede, the Venerable, Saint, 673-735. 8. Alfred, King of England, 849-899.

9. Aelfric, Abbot of Eynsham. I. Title. II. Series: Toronto Anglo-Saxon series ; 26

PR179.P73C63 $2018 \quad$ 829.09'3824832 C2017-904295-5

University of Toronto Press acknowledges the financial assistance to its publishing program of the Canada Council for the Arts and the Ontario Arts Council, an agency of the Government of Ontario.

Canada Council for the Arts
Conseil des Arts du Canada
ONTARIO ARTS COUNCIL CONSEIL DES ARTS DE L'ONTARIO

an Ontario government agency un organisme du gouvernement de I'Ontario 
Lean sceal, gif we leogan nellað, pam pe us pas lisse geteod.

(Return must be made, if we do not wish to deceive, to him who granted us these favors.)

- Maxims II, 1.70 
